\title{
KONFLIK PERKAWINAN DI KABUPATEN SAMBAS
}

\author{
Sri Harjanti \\ Muliaty Amin \\ Baharuddin Ali \\ Amrah Kasim \\ Institut Agama Islam Sultan Muhammad Syafiuddin Sambas \\ Sriharjantiiaiss@gmail.com
}

\begin{abstract}
Abstrak: Tulisan ini akan mengurai tentang konflik perkawinan yang terjadi di Kabupaten Sambas. Jenis penelitian ini adalah penelitian lapangan (Field Reaseach) dengan sifat penelitian deskriptif-analitik. Tipe pendekatan dalam penelitian ini adalah pendekatan fenomenologi, pendekatan dakwah, sosiologi komunikasi dan resolusi konflik. Sumber data primer yaitu pihak Kantor Urusan Agama (KUA), Pengadilan Agama dan pasangan suami istri yang mengalami konflik perkawinan di Kabupaten Sambas. Sedangkan sumber data sekunder adalah berupa buku, arsip, dokumen, catatan-catatan yang berkenaan dengan penelitian. Pengumpulan data dalam penelitian ini menggunakan teknik observasi, wawancara (interview) dan dokumentasi. Aktivitas dalam analisis data meliputi kualitas instrumen dan pengumpulan data. Teknik pengolahan dan analisis data triangulasi, menggunakan bahan referensi, mengadakan member check. Data diuji keabsahan data dalam penelitian ditekankan pada uji validitas dan reabilitas.

Hasil penelitian menunjukkan bahwa jenis konflik perkawinan dalam rumah tangga di Kabupaten Sambas yaitu: faktor pertengkaran, Kekerasan Dalam Rumah Tangga (KDRT) dan faktor suami mabuk. Faktor pertengkaran dilatarbelakangi oleh tidak adanya kesepahaman suami dan isteri, suami pemakai oba-obat terlarang dan suka main judi. Kekerasan dalam rumah tangga berakibat penderitaan fisik maupn psikis. Bentuk kata-kata kasar dan jorok dari suami membuat isteri tersinggung, dilecehkan, tertekan akibat perkataan dan sikap suami; Faktor ekonomi Ekonomi disebabkan tingkat pendapatan suami dibandingkan isteri, isteri tidak dapat mengatur pendapatan suami dengan bijak, ketidakjujuran isteri terhadap suami. Meninggalkan Pasangan, Selingkuh (wanita Idaman Lain/ Pria Idaman Lain) dan Poligami; Faktor dihukum penjara, murtad dan kawin paksa.
\end{abstract}

\section{Keywords: Konflik, Perkawinan, Kekerasan dalam Rumahtangga}

\section{PENDAHULUAN}

Rumahtangga yang harmonis menjadi dasar terbentuknya masyarakat madani yang merupakan pondasi terbentuknya sebuah negara yang baik "Baldatun Thayyibatun" seperti yang diharapkan. Sebaliknya bila suami isteri dalam satu rumahtangga tidak memenuhi hak dan kewajibannya secara sadar dan penuh tanggungjawab, maka akan menimbulkan konflik yang dapat menggangu stabilitas kehidupan keluarga tersebut.

Kehidupan berumahtangga tidak senantiasa harmonis sebagaimana harapan, karenanya berumahtangga butuh pondasi, kesiapan dan kematangan lahir dan batin, terutama berkaitan dengan kompetensi tiap-tiap individu, terutama suami dan istri 
dalam keluarga. Faktor-faktor yang melatarbelakangi perbedaan pada akhirnya mencetuskan konflik berkepanjangan yang ironisnya tidak sedikit berujung konflik yang panjang dan berakhir perceraian. Latarbelakang penyebab konflik dikarenakan perbedaan diantaranya; perbedaan perspektif individu, budaya, kesempatan, nilai, politik dan lainnya. Fenomena tersebut merupakan pokok permasalahan yang terjadi di Kabupaten Sambas.

Dampak perubahan sosial mentransformasi budaya mengalami pergeseran nilai sehingga berimplikasi pada kehidupan glamoritas dan hedonis yang tinggi terhadap perilaku individu di masyarakat. Dikatakan glamoritas dan hedonis mengingat di wilayah Kabupaten Sambas ini sedang merebak pergeseran budaya akibat dari perubahan pola kehidupan kompleks terkait didalamnya, norma, nilai-nilai, moral, hukum, adat istiadat, ilmu pengetahuan, agama dan teknologi. Justru kemajuan tersebut seringkali berdampak negatif sebagai satu diantara pemicu dan faktor persoalan yang berdimensi konflik dalam keluarga dalam sebuah perkawinan.

Permasalahan rumahtangga yang terjadi di Kabupaten Sambas diantaranya dalam bentuk pertengkaran pasangan suami istri, KDRT, ekonomi, perselingkuhan, meninggalkan pasangan, poligami. Kurangnya pengertian antara suami isteri ataupun pemasalahan lain yang berkaitan dalam perkawinan, sering kali tidak bisa terselesaikan secara baik oleh pasangan suami isteri, dengan demikian di nilai sangat memprihatinkan sehingga diperlukan adanya media yang dapat membantu mengatasi segenap permasalahan yang dihadapi suami isteri. ${ }^{1}$

Harapan dan kenyataan senantiasa muncul dimasyarakat dengan fakta ditemukan ketidakharmonisan perkawinan merupakan akar penyebab masalah di Kabupaten Sambas dengan berbagai latarbelakang faktor penyebab masalah konflik. Fenomena tersebut terjadi di beberapa wilayah kecamatan di Kabupaten Sambas diantaranya, Kecamatan Tebas, Kecamatan Pemangkat, dan Kecamatan Sambas, hingga saat penelitian dilakukan masih menjadi potret fenomena tersebut.

Tugas tersebut bersinergis dengan visi dan misi Kementrian Agama. Hal tersebut relevan dengan komitmen Pemerintah Daerah Kabupaten Sambas yang derap pembangunannya dikenal dengan TERPIKAT TERIGAS. TERPIKAT kepanjangan dari tingkatkan ekonomi kerakyatan, religius, pendidikan, dan kesehatan, sedangkan TERIGAS, dari akronim, tertib, teratur, ekonomi, kerakyatan, dan sinergis dalam investasi, religius, iptek, governance, amanah yang akhlakul karimah, sosial control partisipation ${ }^{2}$.

Tingginya presentase angka perceraian perkawinan yang terdata tahun 2014 sampai 2018. Data dari Pengadilan Agama (PA) Kabupaten Sambas tahun 2014, sebanyak 840 perkara, cerai gugat sebanyak 627 perkara, dan cerai talak 144 perkara. Tahun 2016 perkara perceraian di Pengadilan Agama Kabupaten Sambas sebanyak 816 perkara, Tahun 2017 sebanyak 882 perkara dan Tahun 2018 sampai bulan September mencapai angka 550 perkara. ${ }^{3}$ Jika dirunut dari tahun ke tahun jumlahnya bertambah meningkat ${ }^{4}$ dan data tersebut menunjukkan Kabupaten Sambas menempati peringkat ke dua setelah kota Pontianak di Kalimantan Barat. Data faktual tersebut sangat

${ }^{1}$ Cyntia Anggraini, Peran BP4 dalam Mengatasi Problem Perkawinan pada Pasangan Suami Isteri di Kec. Kartasura Kab Sukoharjo, STAIN, 2007, h. 4.

${ }^{2}$ Lihat Pemda Sambas, Bagian Humas.

${ }^{3}$ Data Cerai Talak dan Cerai Gugat di Pengadilan Agama Kabupaten Sambas Tahun 2018

${ }^{4}$ Pontianak.tribunnews.com/2014/03 
memerlukan perhatian khusus bagi semua pihak untuk melakukan preventif dan penyelesaian konflik keluarga dalam perkawinan sehingga dapat menurunkan angka perceraian akibat dari konflik perkawinan. Oleh karena itu, tulisan ini akan mengurai tentang konflik perkawinan yang terjadi di Kabupaten Sambas.

\section{KAJIAN TEORITIK}

\section{A. Masalah Perkawinan}

Pernikahan merupakan wadah sakral pengikat bagi pasangan insan untuk mencapai kebahagian baik didunia maupun diakhirat. Sakralnya sebuah pernikahan dalam rumah tangga menjadi elemen penting bagi setiap pasangan mengembang tanggung jawab bersama sehingga membentuk kebahagian bagi penghuni didalam bahtera tersebut.

Perspektif Islam terkait urgensitas pernikahan memposisikan pernikahan hampir menyamai kemulian agama dikarenakan pernikahan merupakan bukti kekuasaan Allah swt. yang menciptakan kasih sayang dan kerinduan pada makhluk ciptaan-Nya. Dalam perkawinan akan dirasakan ketentraman yang tidak pernah bisa dirasakan oleh orang yang belum menikah, dan hal tersebut hanya bisa dicapai dalam pernikahan yang barokah. ${ }^{5}$ Menikah merupakan perintah dakwah bagi setiap muslim, sebagaimana yang terkandung dalam QS. al-Rum/30:21 sebagai berikut:

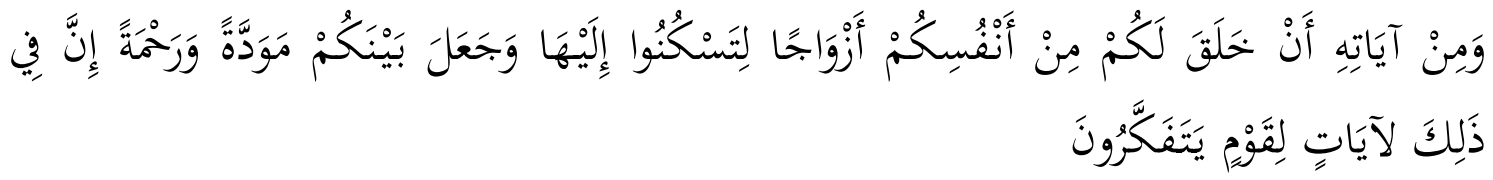

Terjemahnya:

Dan di antara tanda-tanda kekuasaan-Nya ialah Dia menciptakan untukmu isteri-isteri dari jenismu sendiri, supaya kamu cenderung dan merasa tenteram kepadanya, dan dijadikan-Nya diantaramu rasa kasih dan sayang. Sesungguhnya pada yang demikian itu benar-benar terdapat tanda-tanda bagi kaum yang berfikir. $^{6}$

Ayat tersebut menjelaskan bahwa keluarga sakinah merupakan impian dan harapan setiap muslim yang melangsungkan perkawinan dalam rangka melakukan pembinaan keluarga. Inilah ciri khas keluarga sakinah yang Islami. Mereka (suami-istri) berserikat dalam rumah tangga itu untuk berkhidmat kepada aturan dan beribadah kepada Allah swt. ${ }^{7}$

Sebagaimana menurut Rasulullah saw. akan lebih sempurna ketaqwaan seorang mukmin apabila mempunyai seorang istri shalihah; jika diperintah suaminya ia patuh, jika dipandang membuat suaminya senang, jika suaminya bersumpah membuatnya merasa adil, jika suaminya pergi ia akan menjaga dirinya dan harta suaminya. ${ }^{8}$

Harapan dan kenyataan di lapangan ditemukan kesenjangan permasalahan yang ditimbulkan dari konflik rumah tangga dalam pasangan suami istri yang bersama-sama

\footnotetext{
${ }^{5}$ Departemen Agama, Modul Materi Pelatihan Korps Penasihat Perkawinan dan Keluarga Sakinah (Jakarta: Ditjen Bimas Islam dan Penyelenggaraan Haji Proyek Peningkatan Kehidupan Keluarga Sakinah, 2004), h. 85.

${ }^{6}$ Kementrian Agama, Al-quran dan Terjemahnya, h.

${ }^{7}$ Cahyadi Takariawan, Pernik-Pernik Rumah Tangga Islami (Cet. III; Surakarta: Intermedia, 2001), h. 37.

${ }^{8}$ Departemen Agama, Modul Materi Pelatihan Korps Penasihat Perkawinan dan Keluarga Sakinah, h. 85 .
} 
membangun mahligai bahtera perkawinan tersebut, sehingga berdampak pada konflik yang lebih besar menyebabkan perpisahan kedua belah pihak berujung pada perceraian. Hal tersebut sangat ironis dengan melihat berbagai akar permasalahan yang melanda keharmonisan ikatan perkawinan.

\section{Fungsi Perkawinan}

Perkawinan merupakan peristiwa penting dalam kehidupan pasangan antar individu tiap insan manusia. Perkawinan yang terjadi antara seorang pria dengan seorang wanita menimbulkan akibat lahir maupun batin baik terhadap keluarga masing-masing masyarakat dan juga dengan harta kekayaan yang diperoleh diantara mereka baik sebelum maupun selamanya perkawinan berlangsung.

Berlakunya UU Perkawinan, maka terjadi unifikasi hukum dalam perkawinan di Indonesia, dimana perkawinan mempunyai hubungan yang sangat erat dengan agama/kerohanian. Kapasitas sistem hukum tentang perkawinan telah berlaku sama terhadap semua warga Negara karenanya, secara otomatis setiap warga negara wajib patuh terhadap hukum yang berlaku terkait konsekwensi logis. ${ }^{9}$

Sedangkan Wirjono Prodjodikoro menyatakan bahwa perkawinan adalah kesepakatan hidup bersama antara laki-laki dengan perempuan yang memenuhi klasifikasi dan syarat-syarat yang mengikat termasuk dalam peraturan hukum perkawinan. $^{10}$

Tingginya posisi lembaga perkawinan dimata hukum dan UU dilindungi Negara terhadap warga negara, melindungi terkait Hak Azazi Manusia dengan memberikan jaminan perlindungan pada perkawinan, menjamin anggota keluarga, mengikat hubungan dengan konskwensi hak dan kewajiban didalamnya.

\section{Hak dan Kewajiban Suami Istri}

Pengertian hak adalah kekuasaan yang benar atas sesuatu atau untuk menuntut sesuatu. Hak merupakan sesuatu yang wajib diterima. Dengan demikian hak merupakan milik atau dapat dimiliki oleh suami istri yang diperoleh dari pelimpahan hasil perkawinan. Dikatakan demikian disebabkan oleh perolehan sesuatu yang telah dilakukan sesuai dengan proposional kewajiban. Sedangkan pengertian kewajiban, sesuatu yang harus dilakukan sesuai dengan porsi dan tanggung jawabnya.

Konsekwensi sebagai manusia menyandarkan kewajiban merupakan suatu yang alamiah, apalagi jika berbicara tentang rumah tangga yang didalamnya terkait suami istri akan hak dan kewajiban. Pondasi pijakan suami dan istri dalam tatanan rumah tangga harus memiliki pemahaman yang terkandung dalam menjalankan tanggung jawab tersebut. ${ }^{11}$

Pengaturan hak dan kewajiban suami istri dalam perkawinan sejogyanya sebagaimana diatur dalam Undang-undang Perkawinan No.1 Tahun 1974 pasal 30, yaitu suami istri memikul kewajiban yang luhur untuk menegakkan rumah tangga yang menjadi sendi dasar susunan rumah tangga ${ }^{12}$, dan Pasal 77 ayat 1 yaitu suami istri memikul kewajiban yang luhur untuk menegakkan rumah tangga yang sakinah, mawaddah dan rahmah yang menjadi sendi dasar dan susunan masyarakat ${ }^{13}$.

\footnotetext{
${ }^{9}$ K. Wantjik Saleh, Hukum Perkawinan Indonesia (Jakarta Timur, Ghalia Indonesia 1982), h. 3.

${ }^{10}$ Soetojo Prawirohamidjojo dkk, Hukum Orang dan Keluarga (Bandung, Alumni, Cetakan Kesebelas, 2000), h.10.

${ }^{11}$ Firdaweri, Hukum Islam Tentang Fasakh Perkawinan (CV. Pedoman Ilmu Jaya, 1989), h. 7-8.

${ }^{12}$ Undang-undang No. 1 Tahung 1974 Tentang Perkawinan dan Kompilasi Hukum Islam, h. 13.

${ }^{13}$ Abdul Rahman Ghozali, Fiqih Munakahat (Jakarta: Kencana, 2003), cet ke-3, h. 132.
} 
Selain hal tersebut, masih banyak tugas dari fungsi suami dan istri. Dapat di lihat tugas dan tanggungjawab suami meliputi: ${ }^{14}$

a. Menyadari bahwa istri sebagai amanat dari Allah swt. yang harus dipertanggungjawabkan di hadapan Allah dalam segala sesuatu yang menjadi kewajibannya.

b. Menafkahi istri dan rumah tangganya. Selain itu suami juga harus mampu menjaga keluarganya dari bencana dan bahaya.

c. Menjadi pemimpin dalam beribadah kepada Allah swt.

d. Menjadi kepala rumah tangga dan pemimpin keluarga yang adil, bijaksana dan lemah lembut.

e. Selalu bersabar bila melihat sesuatu yang tidak disukai dari istrinya dan berusaha untuk membimbingnya kearah yang lebih baik.

f. Suami adalah pemimpin, pelindung dan pembimbing dalam rumah tangga, seperti tercantum dalam Q.S An-Nisa/4 ayat 34 yang artinya, "Kaum laki-laki (suami) adalah pemimpin (pembela dan pelindung) bagi kaum wanita (istri), karena Allah telah melebihkan yang satu dari yang lainnya dank arena suami telah menafkahkan sebagian dari hartanya".

Demikian juga sebagai seorang istri juga memiliki tugas, fungsi dan tanggung jawab diantaranya: ${ }^{15}$

1. Menyadari dirinya adalah bagian dari amanat yang diserahkan Allah swt. Pada suaminya.

2. Pembina sekaligus ibu rumah tangga yang bertanggungjawab atas harta benda milik suami dan pendidikan atas anak-anaknya.

3. Sebagai penstabil dan penyelamat rumah tangga yang mampu menjadi sumber ketenagan bagi jiwa suami dan anak-anaknya.

4. Berusaha menjadi istri yang shalehah, yang mengetahui kewajiban terhadap Tuhan-Nya dan terhadap suaminya.

5. Selalu berusaha menyenangkan bila dilihat suaminya, selalu menuruti kehendak suaminya selama tidak bertentangan dengan perintah Allah swt. Dan tidak menyelewengkan dirinya serta harta suaminya ke jalan yang tidak di sukai suaminya.

Substansi terkait hak dan kewajiban suami istri dipandang sangat sinergis selama menjalankan rumah tangga memenuhi kesadaran dan pemahaman terkait tujuan rumah tangga yang dibangun dalam perkawinan menuju muara kebahagian. Bias gender membentuk pranata sosial akan kewajiban dan hak suami istri sesuai dengan kondisi kontekstual yang disepakati dalam rumah tangga.

\section{Tujuan Perkawinan}

Perkawinan merupakan suatu hal yang urgen dalam realitas kehidupan manusia, oleh sebab itu sepantasnya manusia untuk meneruskan kelangsungan hidup dan keturunannya dengan cara halal sesuai dengan syariat Islam yaitu dengan melakukan perkawinan seperti yang dicontohkan Rasulullah saw. ${ }^{16}$

Tujuan perkawinan sebagaimana yang terkandung dalam QS Ar-Rūm/30:21 h. $91-92$

${ }^{14}$ Departemen Agama, Modul Materi Pelatihan Korps Penasihat Perkawinan dan Kelurga Sakinah, h. $92-93$

${ }^{15}$ Departemen Agama, Modul Materi Pelatihan Korps Penasihat Perkawinan dan Kelurga Sakinah,

${ }^{16}$ Has Kadri, Adat Istiadat Perkawinan Melayu Sambas (Pontianak: Romeo Grafika, 2000), h. 2. 


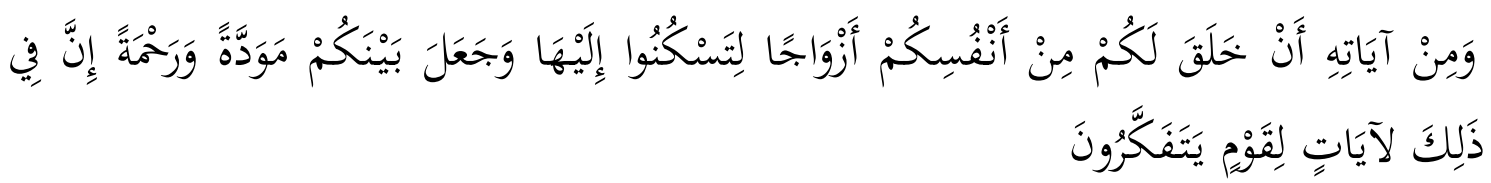

Terjemahnya:

Dan di antara tanda-tanda kekuasaan-Nya ialah Dia menciptakan untukmu isteriisteri dari jenismu sendiri, supaya kamu cenderung dan merasa tenteram kepadanya, dan dijadikan-Nya diantaramu rasa kasih dan sayang. Sesungguhnya pada yang demikian itu benar-benar terdapat tanda-tanda bagi kaum yang berfikir. ${ }^{17}$

Tujuan perkawinan dalam Islam adalah untuk memenuhi kebutuhan naluriah hidup manusia, berhubungan antara laki-laki dan permpuan dalam rangka mewujudkan kebahagian keluarga sesuai ajaran Allah dan Rasul-Nya. ${ }^{18}$

Merujuk Undang-undang perkawinan perkawinan Nomor 1 Tahun 1974 Pasal 1, tujuan perkawinan yaitu membentuk keluarga (rumah tangga) yang bahagia dan kekal berdasarkan Ketuhanan Yang Maha Esa dengan melangsungkan pernikahan akan memperoleh suatu keberhasilan baik material maupun spiritual. ${ }^{19}$

Paparan tersebut dapat disimpulkan, bahwa tujuan pernikahan yaitu untuk membentuk keluarga harmonis, menjalin hubungan yang bersifat kekal antara suami istri secara legalitas, serta untuk mendapatkan garis keturunan yang sah. Sebagaimana dijabarkan sebelumnya bahwa tanpa adanya kesepahaman, pengertian yang mendalam dari tujuan perkawinan, hal tersebut dapat menjadi akar permasalahan bagi keluarga.

\section{B. Masalah Konflik}

Pijakan yang peneliti gunakan dalam karya tulis ini yaitu berorientasi sepenuhnya kepada fakta kehidupan menunjukkan bahwa tidak sedikit perkawinan yang dibangun dengan susah payah pada akhirnya bubar karena kemelut rumah tangga yang tidak dapat terselesaikan.

\section{Pengertian Konflik}

Sedangkan istilah Webster "conflict", dalam bahasa aslinya adalah suatu "perkelahian, peperangan, atau perjuangan", yaitu berupa konfrontasi fisik antara beberapa pihak. Tetapi arti kata tersebut kemudian berkembang menjadi "ketidaksepakatan yang tajam atau oposisi terhadap beberapa kepentingan, ide, dan lain-lain".

Menurut William Hendricks suatu konflik dipandang dari dua perspektif: bahaya dan kesempatan. ${ }^{21}$ Sedangkan pendapat klasik mengatakan, konflik identik dengan bahaya. Bagi yang sependapat dengan pendapat ini, dengan terjadinya konflik,

\footnotetext{
${ }^{17}$ Kementrian Agama RI, Al-Qur'an dan Terjemahannya (Bandung: Semesta Al-Qur'an, 2013) h. 406.

${ }^{18}$ A. Basyir, Hukum Perkawinan Islam (Yogyakarta: Bagian Penerbitan Fakultas Hukum Universitas Islam Indonesia, 1987), h. 11.

${ }^{19}$ Bimo Walgito, Bimbingan dan Konseling Perkawinan (Yogyakarta: Penerbit Andi), h. 13.

${ }^{20}$ Mengutip Dean, G. Pruitt dan Jeffrey Z. Rubin, Social Conflict Escalation, Stalemate, and Settlement, terj. Helly P. Soetjiptodan Sri Mulyantini Soetjipto, Teori Konflik Sosial (Yogyakarta: Pustaka Pelajar, 2004), h. 9.

${ }^{21}$ William Hendricks, Bagaimana Mengelola Konflik: Petunjuk Praktis untuk Manajemen Konflik yang Efektif, terj. Ariff Santoso (Jakarta: Bumi Aksara, 1996), h. 2.
} 
maka tujuan atau situasi dapat menjadi chaos, karena itu sedapat mungkin harus dihindarkan atau dicegah. ${ }^{22}$

Menurut kosa kata Inggris terdapat 2 (dua) istilah, yakni "conflict", dan "dispute" yang kedua-duanya mengandung pengertian tentang adanya perbedaan kepentingan di antara kedua belah pihak atau lebih, tetapi keduanya dapat dibedakan. Kosa kata conflict sudah diserap kedalam bahasa Indonesia menjadi "konflik", sedangkan kosa kata "dispute" dapat diterjemahkan "sengketa". Sebuah konflik, yakni sebuahs ituasi di mana 2 (dua) pihak atau lebih dihadapkan pada perbedaan kepentingan, tidak akan berkembang menjadi sebuah sengketa bila mana pihak yang merasa dirugikan telah menyatakan rasa tidak puas atau keprihatinannya, baik secara langsung kepada pihak yang dianggap sebagai penyebab kerugian atau kepada pihak lain. $^{23}$

\section{Jenis-jenis Konflik}

Menurut Juanita pengajar USU yang mengutip pendapat James A.F. Stoner dan Charles Wankel menjelaskan bahwa konflik itu ada lima jenis, yaitu konflik intrapersonal, konflik interpersonal, konflik antara individu dengan suatu kelompok, konflik antar kelompok dalam satu organisasi, dan konflik antar organisasi. ${ }^{24}$ Dari jenis konflik yang terjadi sepanjang kehidupan manusia tersebut konflik dengan berbagai pengertiannya sebagai berikut: ${ }^{25}$

a. Konflik intrapersonal ialah konflik yang terjadi di dalam diri seseorang

b. Konflik interpersonal adalah pertentangan antara seseorang dengan orang lain,

c. Konflik antara individu dengan kelompok. Hal ini seringkali berhubungan dengan cara individu menghadapi tekanan-tekanan untuk mencapai konfomnitas.

d. Konflik antar organisasi. Misalnya suatu perusahan berkompetisi dengan perusahan lain untuk meraih konsumen sebanyak-bayaknya.

\section{Faktor Penyebab Konflik}

Akar konflik adalah perbedaan, di antara perbedaan tersebut meliputi perpektif, wacana, kultur, agama, ekonomi pengetahuan dan lain sebagainya, yang dikonstuktif dari berbagai dimensi menurut subyektifitas perspektif individu terhadap komunitas hidupnya yang mengalami perberbedaan.

Perbedaan ini hadir secara alami karena terbentuk oleh dasar-dasar bawaan prinsip dari keyakinan (belief) dan pandangan hidup (worlrd view), ke dua wilayah ini dibentuk oleh kepentingan-kepentingan untuk mempertahankan diri atau kelompok. Dengan demikian konflik tidak bisa terlepas dari kehidupan sosial. ${ }^{26}$

Menurut Karl Marx penyebab terjadinya konflik karena sejarah kehidupan masyarakat ditentukan oleh materi atau benda yang berbentuk alat produksi sebagai penguasa kehidupan masyarakat, berupa ekonomi sebagai produk terpenting dan sebagai faktor yang dijadikan kekuataan kekuasaan. Bentuk-bentuk konflik yang

\footnotetext{
${ }^{22}$ John Paul Lederach, The Little Books Conflict Transformatio (USA: Good Books, 2003), h. 23.

${ }^{23}$ Rachmadi Usman, Pilihan Penyelesaian Sengketa di Luar Pengadilan (PT. Citra Aditya Sakti:

${ }^{24}$ http://library.usu.ac.id/download/fkm/fkm-juanita3.pdf, diakses tanggal 1 April 2016.

${ }^{25}$ http:///library.usu.ac.id/download/fkm/fkm-juanita3.pdf diakses tanggal 1 April 20116.

${ }^{26}$ Amin Abdullah, Agama dan Resolusi Konflik makalah seminar Nasional (Yogyakarta: 14 Maret
} 2003). h. 1-2. 2008), h. 1. 
terstruktur antara berbagai individu dan kelompok muncul terutama melalui terbentuknya hubungan-hubungan pribadi dalam produksi. ${ }^{27}$

Beberapa pandangan Karl Mark mengemukakan terkait kehidupan sosial yaitu:

a. Masyarakat sebagai arena yang didalamnya terdapat berbagai bentuk pertentangan.

b. Negara dipandang sebagai pihak yang terlibat aktif dalam petentangan dengan berpihak kepada kekuatan yang dominan.

c. Paksaan (coercion) dalam wujud hukum dipandang sebagai faktor utama untuk memelihara lembaga-lembaga sosial.

d. Negara dan hukum dilihat sebagai alat penindasan yang digunakan oleh kelas yang berkuasa (kapitalis) demi keuntungan mereka.

e. Kelas-kelas dianggap sebagai kelompok-kelompok sosial yang mempunyai kepentingan sendiri yang bertentangan satu sama lain, sehingga konflik tak terelakkan lagi. $^{28}$

Faktor-faktor yang menyebabkan terjadinya konflik diantaranya:

1) Perbedaan pendirian

Yaitu keyakinan orang perorangan yang telah menyebabkan konflik antar individu.

2) Perbedaan budaya

Perbedaan Kebudayaan tidak hanya menimbulkan konflik antar individu akan tetapi bias juga antar kelompok. ${ }^{29}$

Selanjutnya faktor-faktor penyebab konflik sosial yang lain diantaranya:

1) Perbedaan antar perorangan

Perbedaan ini dapat berupa perbedaan perasaan, pendirian atau pendapat.

2) Perbedaan kebudayaan

Perbedaan kebudayaan mempengaruhi pola pemikiran dan tingkah laku perseorangan dalam kelompok kebudayaan yang bersangkutan.

3) Bentrokan kepentingan

Bentrokan kepentingan dapat terjadi di bidang ekonomi, politik dan sebagainya.

4) Perubahan sosial yang terlau cepat di dalam masyarakat

Perubahan tersebut dapat menyebabkan terjadinya disorganisasi dan perbedaan pendirian mengenai reorganisasi dari sistem nilai yang baru. ${ }^{30}$

Sedangkan faktor-faktor lain yang menyebabkan timbulnya konflik dalam kehidupan berumah tangga juga dapat disebabkan oleh:

a. Faktor kerusakan akhlak.

Dimaksudkan di sini adalah apabila salah seorang atau kedua-duanya melakukan penyimpangan moral atau akhlak seperti:

1. Berzina, yaitu melakukan hubungan seks bukan dengan isterinya atau suaminya.

2. Serong, yaitu adanya ketidakjujuran dari salah satu pihak atau keduanya.

3. Judi.

b. Faktor ekonomi.

Dimaksudkan di sini adalah:

\footnotetext{
${ }^{27}$ David Berry, Pokok-pokok Pikiran dalam Sosiologi (Jakarta: PT. Raja Grafindo Persada, 2004), h. 129.

${ }^{28}$ Poloma Margaret, Sosiologi Kontemporer (Jakarta: Raja Grafindo Persada, 2010), h. 258.

${ }^{29}$ Ritha Safithri, Mediasi dan Fasilitas Konflik dalam Membangun Perdamaian, h. 674.

${ }^{30}$ Faktor-Faktor Penyebab Konflik, https://www.siswapedia.com, diakses 05 Januari 2019.
} 
1. Kurang terbukanya antara suami isteri dalam pengelolaan ekonomi rumah tangga.

2. Berkurangnya sumber nafkah keluarga.

3. Bertambahnya kebutuhan rumah tangga tidak sejalan dengan peningkatan penghasilan.

4. Sibuknya suami isteri dalam mencari nafkah sehingga kehidupan rumah tangga tidak terurusi.

c. Faktor biologis.

Dimaksudkan di sini adalah adanya hambatan pada salah seorang suami isteri dalam hal biologis yang dapat menimbulkan ketidakharmonisan rumah tangga tersebut, antara lain seperti:

1. Suami atau isteri tidak dapat menjalankan fungsinya.

2. Belum atau tidak mempunyai keturunan.

3. Perbedaan usia yang terlalu jauh.

4. Terjadi kesenjangan dalam latar belakang pendidikan.

5. Di antara suami isteri terjadi penyimpangan seksual seperti lesbian, homoseks, hiperseks, impoten dan frigid.

d. Faktor pihak ketiga.

Yang dimaksudkan pihak ketiga ini adalah adanya campur tangan orang lain terhadap kehidupan rumah tangga seseorang sehingga terjadi konflik ketidakharonisan rumah tangga tersebut. Sebagai akibat campur tangan pihak ketiga itu antara lain:

1. Faktor kecemburuan di antara kedua belah pihak.

2. Campur tangan mertua atau saudara terhadap urusan rumah tangga seseorang.

3. Masalah saudara ipar yang ikut numpang dalam rumah tangga.

4. Masalah pembantu rumah tangga seperti isteri mencurigai suami berbuat serong dengan pembant unya atau sebaliknya.

5. Masalah poligami.

e. Faktor salah paham.

Di antara faktor-faktor yang dapat meyebabkan salah paham dalam suatu rumah tangga antara lain:

a. Perkawinan antar suku yang berbeda, sehingga menyebabkan salah paham dalam suatu rumah tangga.

b. Perbedaan cara dalam mendidik anak.

f. Faktor politik.

Dimaksudkan di sini adalah terjadinya perbedaan interns politik antara suami isteri seperti dalam masalah pemilihan umum, yang menimbulkan ketegangan dalam rumah tangga tersebut. ${ }^{31}$

Adanya suatu indikasi konflik dalam rumah tangga adalah manakala komunikasi diantara suami isteri tidak berjalan, dan pola interaksi yang terbangun di antara keduanya memiliki kondisi yang menegangkan. Banyaknya penyebab terjadinya konflik antara suami isteri, dengan berbagai permasalahan dan alasan seperti Kekerasan Dalam Rumah Tangga, ekonomi yang minim, suami atau isteri mempunyai pasangan lain (wanita idaman lain/pria idaman lain) dan meninggalkan tanggungjawab

${ }^{31} \mathrm{H}$. Ali Akbar, Dasar-Dasar Konseptual Penanganan Masalah Bimbingan dan Konseling Islami dalam Bidang Pernikahan: dalam Rumusan Seminar Nasional Bimbingan dan Konseling Islami II (Yogyakarta: UUI Badan Pembinaan dan Pemgembangan Keagamaan, 1987), h. 10-12. 
oleh suami maupun isteri. Sehingga perubahan mendasar tersebut menjadi penyebab dari munculnya konflik suami isteri.

\section{Dampak Konflik Perkawinan}

Persoalan penyebab konflik perkawinan dipandang banyak yang melatarbelakangi, baik dari hal terkecil hingga yang terbesar. Orientasi area besar dapat dijumpai persoalan akibat dampak lajunya arus globalisasi yang dihadapi bangsabangsa di dunia tak terkecuali khususnya Indonesia. ${ }^{32}$ Pendapat Dadang Hawari terkait wujud perubahan tersebut dapat diidentifikasikan diantaranya: perubahan pada aspek nilai moral, etik, kaidah agama dan pendidikan anak dirumah, pergaulan dan pekawinan. Diantara satu dampak perubahan tersebut yakni terancamnya lembaga perkawinan dan keluarga yang merupakan lembaga dini bagi anak dan remaja. ${ }^{33}$

Perubahan-perubahan yang ditimbulkan dari dampak globalisasi khususnya mengancam lembaga perkawinan berpengaruh terhadap fungsi, kedudukan dan peran orangtua di intern institusi keluarga. Perubahan dan pergeseran peran keluarga sebagai pelindung dan kedamaian, dasar-dasar pergaulan hidup, unit sosial ekonomis, serta proses sosialisasi awal dalam kehidupan bermasyarakat sudah jauh dari ideal sebab sebagai tuntutan hidup bagi keluarga modern. ${ }^{34}$ Sisi lain dampak negatif yang dimuncukan dalam interaksi sosial dalam keluarga yang tidak dapat dikendalikan merupakan satu indikator faktor penyebab rapuhnya keutuhan dan kehidupan berkeluarga bahkan berujung pada perceraian. ${ }^{35}$

Berdasarkan data tersebut menunjukkan indikasi dampak konflik perkawinan dilatarbelakangi faktor-faktor pemicu (trigger) yang menimbulkan dampak signifikan terhadap sebuah ikatan perkawinan. Beberapa diantaranya sangat berdampak kepada anggota dari unit keluarga didalamnya. Sehingga menimbulkan kondisi hubungan keluarga tidak berjalan dengan baik sesuai harapan dan tujuan perkawinan yakni mewujudkan keluarga sakinah, mawaddah dan warohmah.

\section{METODOLOGI PENELITIAN}

Jenis penelitian ini adalah penelitian lapangan (Field Reaseach) dengan sifat penelitian adalah deskriptif-analitik. Pendekatan dalam penelitian ini adalah pendekatan fenomenologi, pendekatan dakwah, sosiologi komunikasi dan resolusi konflik. Sumber data primer yaitu sumber data yang berupa manusia/orang dan menjadi informan kunci (key informan). Pihak-pihak yang dianggap paling mengetahui masalah yang berhubungan dengan penelitian yang sedang dilakukan ${ }^{36}$ Kantor Urusan Agama (KUA), Pengadilan Agama dan pasangan suami istri yang mengalami konflik perkawinan di Kabupaten Sambas. Adapun sumber data sekunder adalah berupa buku,

\footnotetext{
${ }^{32}$ Arus globalisasi merupakan akar persoalan besar yang dihadapi setiap bangsa di penjuru dunia berdampak langsung pada manusia, bias modernisasi dan westernisasi, konteks sesuai budaya, ekonomi, politik dan institusional di Barat, meningkat tajam imperialisme cultural (George Ritzer dan Douglas J. Goodman, Teori Sosiologi Modern, terj. (Jakarta: Kencana ranada Media Group, 2008), cet ke-5, h. 587588 .

${ }^{33}$ Dadang Hadari, Al-qur'an Ilmu Kedokteran dan Kesehatan Jiwa (Yogyakarta: Dana Bakti rima Yasa, 1997), h. 165-166.

${ }^{34}$ Soerjono Soekanto, Sosiologi Keluarga: Tentang Ikhwal Keluarga Remaja dan Anak (Jakarta: Rineka Cipta, 2004), cet ke-3, h. 23.

${ }^{35}$ EB Surbakti, Sudah Siapkan Menikah (Jakarta: Kompas Gramedia, 2008), h. 70.

${ }^{36}$ Lihat Burhan Bugin, Analisis Data Penelitian Kualitatif: Pemahaman Filosofis dan Metodologis ke Arah Penguasaan Model Aplikasi (Cet: I; Jakarta: Grafindo Persada, 2005), h. 53.
} 
arsip, dokumen, catatan-catatan yang berkenaan dengan penelitian. Upaya pengumpulan data dalam penelitian ini, teknik observasi, wawancara (interview) dan dokumentasi. Analisis data meliputi kualitas instrumen dan pengumpulan data. Selanjutnya langkah-langkah teknik pengolahan dan analisis data triangulasi, menggunakan bahan referensi, mengadakan member check. Data diuji keabsahan data dalam penelitian ditekankan pada uji validitas dan reabilitas.

\section{HASIL PENELITIAN DAN PEMBAHASAN}

\section{A. Bentuk Konflik dan Resolusi Konflik}

Tujuan perkawinan dalam Islam untuk membentuk keluarga sakinah yang didalamnya terdiri dari keluarga inti yang saling berinteraksi dan saling melakukan proses penyesuaian bersama-sama. Proses adapatasi seringkali tidak menemukan satu tujuan yang sama dikarenakan latarbelakan faktor, perbedaan individu, budaya, kepentingan dan nilai yang meliputi dalam ikatan perkawinan.

Bentuk konflik perkawinan yang terjadi di Kabupaten Sambas dilihat dari akar konflik yang terjadi dikarenakan pertentangan antara seseorang dengan orang lain yaitu antara suami dan istri. Konflik demikian kemungkinan besar akan mempengaruhi proses pencapaian tujuan perkawinan. Bentuk konflik perkawinan yang terjadi di Kabupaten Sambas diantaranya, pertengkaran, Kekerasan Dalam Rumah Tangga, suami mabuk, ekonomi, meninggalkan pasangan, selingkuh, dan poligami, du hukum penjara, murtad dan kawin paksa.

\section{Jenis-jenis konflik}

Akar konflik adalah perbedaan, di antara perbedaan tersebut meliputi perpektif, wacana, kultur, agama, ekonomi pengetahuan dan lain sebagainya, yang dikonstuktif dari berbagai dimensi menurut perspektif individu terhadap komunitas hidupnya yang mengalami perberbedaan.

Perbedaan ini hadir secara alami karena terbentuk oleh dasar-dasar bawaan prinsip dari keyakinan (belief) dan pandangan hidup (worlrd view), ke dua wilayah ini dibentuk oleh kepentingan-kepentingan untuk mempertahankan diri atau kelompok. Dengan demikian konflik tidak bisa terlepas dari kehidupan sosial. Meski demikian konflik tidak akan membuat manusia bertahan hidup dalam pertentangan dan perselisihan terus menerus. $^{37}$

Menurut Juanita pengajar USU yang mengutip pendapat James A.F. Stoner dan Charles Wankel menjelaskan bahwa konflik itu ada lima jenis, yaitu konflik intrapersonal, konflik interpersonal, konflik antara individu dengan suatu kelompok, konflik antar kelompok dalam satu organisasi, dan konflik antar organisasi. ${ }^{38}$

Menurut pendapat Hurlock bahwa perkawinan tidaklah semudah yang diinginkan setiap orang karena didalmnya terdapat banyak konsekwensi yang harus dihadapi. Sebagai proses dan tahap kehidupan baru bagi individu dewasa dan pergantian status lajang menjadi pasangan suami istri yang dituntut adanya kesiapan dan adapatasi terus menerus sepanjang perkawinan. ${ }^{39}$

${ }^{37}$ Amin Abdullah, Agama dan Resolusi Konflik makalah seminar Nasional (Yogyakarta: 14 Maret 2008), h. 1.

${ }^{38}$ http://library.usu.ac.id/download/fkm/fkm-juanita3.pdf, diakses Tanggal 22 Oktober 2017.

${ }^{39}$ Hurlock, Psikologi Perkembangan Suatu Pendekatan Sepanjang Rentang Kehidupan (Jakarta: Erlangga), h. 246-248. 
Diperlukan kemampuan penyesuaian setiap individu dan memiliki persiapanpersiapan dalam menjalani kehidupan berkeluarga akan memudahkan proses kelangsungan konsekwensi persolan yang timbul dalam perkawinan. Bagi individu yang belum memiliki kesiapan membangun perkawinan dianggap belum disebut layak sehingga dianjurkan untuk melakukan penundaan atau pendewasaan usia perkawinan. ${ }^{40}$

Jika direlevansikan dengan persoalan rumah tangga dalam bingkai pernikahan konflik suami istri yang terjadi di Kabupaten Sambas mengindikasikan konflik interpersonal dan Konflik antara individu dengan kelompok, sebagaimana temuan data dilapangan bahwa konflik dilatarbelakangi perbedaan pendapat, prinsip, pola kebiasaan, pertengkaran, dan intervensi rumah tangga oleh berbagai pihak, diantaranya, dari keluarga suami dan istri.

Penelitian menggunakan data dari tahun Tahun 2017 sebanyak 882 perkara dan Tahun 2018 sampai bulan September mencapai angka 550 perkara. Data tersebut secara jelas dapat dilihat dari tahun 2017 sampai 2018 dengan komponen permasalahannya terklasifikasi sebagai berikut, faktor konflik perselisihan dan pertengkaran berjumlah 535 perkara, konflik yang disebabkan meninggalkan salah satu pihak berjumlah 412 perkara, faktor konflik ekonomi berjumlah, 146 perkara, faktor konflik disebabkan judi berjumlah, 17 perkara, faktor disebabkan mabuk berjumlah 10 perkara, faktor konflik disebabkan Kekerasan dalam Rumah Tangga berjmlah, 8 perkara, faktor konflik disebakan zina berjumlah 4, faktor konflik disebabkan di hukum penjara berjumlah 3, faktor konflik disebabkan kawin paksa berjumlah 2 perkara.

Dari keseluruhan jumlah tersebut terdapat berbagai faktor yang menyebabkan konflik dalam perkawinan, sebagaimana hal tersebut dapat dilihat pada tabel 4.1 dan pada tabel 4.2 sebagai berikut:

${ }^{40}$ htt://WwW.averroes.or.id/research/hubungan-sikap-terhadap-penundaan-usia-perkawinandengan-intensi-penundaan-perkawinan.html, diakses tanggal, 15 Desember 2017. 
Tabel 4.1 Laporan Penyebab Terjadinya Perceraian Pengadilan Agama Islam

Kabupaten Sambas 2017

\begin{tabular}{|c|c|c|c|c|c|c|c|c|c|c|c|c|c|c|}
\hline \multirow{2}{*}{ Bulan } & \multicolumn{13}{|c|}{ Penyebab Terjadinya Perceraian } & \multirow[b]{2}{*}{ Jumlah } \\
\hline & Zina & Mabuk & $\begin{array}{l}\text { Pihak } \\
\text { ke } \\
\text { Tiga }\end{array}$ & Judi & $\begin{array}{c}\text { Meninggalkan } \\
\text { Salah Satu } \\
\text { Pihak }\end{array}$ & $\begin{array}{c}\text { Poliga- } \\
\text { mi }\end{array}$ & $\begin{array}{l}\mathrm{KD} \\
\mathrm{RT}\end{array}$ & $\begin{array}{l}\text { Cacat } \\
\text { Badan }\end{array}$ & $\begin{array}{l}\text { Perselisihan } \\
\text { dan } \\
\text { Pertengkaran }\end{array}$ & $\begin{array}{c}\text { Kawin } \\
\text { Paksa }\end{array}$ & $\underset{\mathrm{d}}{\text { Murta }}$ & $\begin{array}{c}\text { Ekon } \\
\text { mi }\end{array}$ & $\begin{array}{c}\text { Di } \\
\text { Hukum } \\
\text { Penjara }\end{array}$ & \\
\hline Januari & & & & 2 & 18 & & & & 14 & & & 13 & & \multirow{12}{*}{804} \\
\hline Februari & & & & 4 & 12 & & & & 13 & & & & & \\
\hline Maret & & & & 4 & 22 & & & & 51 & & 2 & 8 & & \\
\hline April & & & & 4 & 16 & & & & 31 & & & 4 & & \\
\hline Mei & & 1 & & 1 & 26 & & & & 28 & & & & 1 & \\
\hline Juni & 1 & & & & 18 & & & & 21 & & & 5 & 1 & \\
\hline Juli & & & & & 41 & 1 & & & 28 & & & 16 & & \\
\hline Agustus & & 1 & & & 37 & & & & 44 & & 1 & 16 & & \\
\hline September & & & & & 32 & & & & 29 & & & 17 & & \\
\hline Oktober & & & & 1 & 15 & 1 & 1 & & 24 & & & 12 & 1 & \\
\hline Nopember & & 1 & & & 20 & 3 & & & 33 & & & & & \\
\hline Desember & & 1 & & & 45 & 2 & 1 & & 45 & & & 14 & & \\
\hline Jumlah & 1 & 4 & 0 & 16 & 302 & 7 & 2 & 0 & 361 & 0 & 3 & 105 & 3 & \\
\hline
\end{tabular}

Sumber Data: Pengadilan Agama Kabupaten Sambas 2017 
Table 4.2 Laporan Penyebab Terjadinya Perceraian Pengadilan Agama Islam

Kabupaten Sambas 2018

\begin{tabular}{|c|c|c|c|c|c|c|c|c|c|c|c|c|c|c|}
\hline \multirow{2}{*}{ Bulan } & \multicolumn{13}{|c|}{ Penyebab Terjadinya Perceraian } & \multirow[t]{2}{*}{ Jumlah } \\
\hline & Zina & Mabuk & $\begin{array}{c}\text { Pihak } \\
\text { ke } \\
\text { Tiga }\end{array}$ & Judi & $\begin{array}{l}\text { Meninggalkan } \\
\text { Salah Satu } \\
\text { Pihak }\end{array}$ & Poligami & $\begin{array}{c}\text { KDR } \\
\text { T }\end{array}$ & $\begin{array}{l}\text { Cacat } \\
\text { Badan }\end{array}$ & $\begin{array}{c}\text { Perselisihan } \\
\text { dan } \\
\text { Pertengkara } \\
\text { n }\end{array}$ & $\begin{array}{l}\text { Kawi } \\
\text {-n } \\
\text { Paksa }\end{array}$ & Murtad & $\begin{array}{c}\text { Ekono } \\
\text {-mi }\end{array}$ & $\begin{array}{c}\text { Di } \\
\text { Hukum } \\
\text { Penjara }\end{array}$ & \\
\hline Januari & 1 & & 1 & & 24 & 1 & & & 33 & 1 & & 5 & & \multirow{5}{*}{353} \\
\hline Februari & & 1 & & & 24 & 3 & & & 34 & 1 & & 6 & & \\
\hline Maret & 1 & 1 & & 2 & 24 & 1 & & & 34 & & & 7 & & \\
\hline April & 1 & 2 & & 1 & 18 & 2 & 1 & & 33 & & & 9 & & \\
\hline Mei & & 2 & & 2 & 19 & & 3 & & 40 & & & 14 & & \\
\hline Jumlah & 3 & 7 & 1 & 5 & 109 & 7 & 4 & 0 & 174 & 2 & 0 & 41 & 0 & \\
\hline
\end{tabular}


Tabel 4.1 dan tabel 4.2 di atas menunjukkan bahwa faktor-faktor yang menyebabkan konflik perkawinan dalam rumah tangga yang bermasalah dapat dilihat dari paparan berikut yaitu, faktor pertengkaran berjumlah 255 perkara, meninggalkan pasangan berjumlah 411 perkara, ekonomi berjumlah 146 perkara, judi berjumlah 21 perkara, poligami berjumlah 14 perkara, mabuk berjumlah 11 perkara, KDRT berjumlah 6 perkara, zina berjumlah 4 perkara, murtad berjumlah 3 perkara, di hukum penjara berjumlah 3 perkara dan kawin paksa berjumlah 2 perkara. Jumlah keseluruhan perkara akibat konflik dalam perkawinan di Kabupaten Sambas dari tahun 2017 sampai bulan September 2018 berjumlah 1.157 perkara.

1. Faktor pertengkaran, Kekerasan Dalam Rumah Tangga (KDRT) dan Faktor Suami Mabuk

Sedangkan pengertian kekerasan terhadap perempuan, yang telah menjadi tema global, dapat dilihat dari ditetapkannya instrument hukum Internasional, diantaranya:

1) "Vienna Declaration and Programme of Action (1993)

2) Convention of the Elimination of All Forms of Discrimination Against Women (1979)

3) Declaration on the Elimination of Violence Against Women (1993)

4) Beijing Declaration and Plat Form For Action (1995)"41

Dalam bentuk yang lainnya kekerasan dapat berupa kekerasan fisik, kekerasan psikis dan kekerasan ekonomi. Kekerasan fisik ada beragai macam, bentuknya antara lain memukul, melempar dengan keras, menyinggung, membakar atau menyiram dengan air panas, memasukkan dalam es, tangan besi, menolak hubungan atas permintaan isteri dan lain-lain yang dapat membahayakan keselamatan perempuan. Sedangkan kekerasan psikis dapat berupa subyektifis suami, dibawah tekanan, perangai, menghina, problem kesehatan, dan ekploitasi. ${ }^{42}$

Ada beberapa faktor-faktor yang dapat menyebabkan kekerasan terjadi di rumah tangga, dalam hal ini kekerasan dalam rumah tangga dapat timbul dengan beberapa faktor pendorongnya, antara lain: ${ }^{43}$ Masalah komunikasi dan kepercayaan, hal ini sangat penting dalam suatu hubungan dan tidak menutup kemungkinan jika komunikasi dan kepercayaan tidak terbangun dengan baik akan menimbulkan suatu konflik.

a) Masalah kedudukan dari suami dan istri dalam suatu rumah tangga di mana hal ini bukan tidak jarang merupakan salah satu faktor penyebab apalagi jika tidak ada kesepahaman antar pasangan.

\footnotetext{
${ }^{41}$ Achi sudiarti Ulinnuha, SH, MA (ed), --Pemahaman Bentuk-Bentuk Tindak Kekerasan Terhadap Perempuan dan Alternatif Pemecahannya (Jakarta: UI Press, 2000), h. 101.

${ }^{42}$ James Calleja, Aged Population, violence and Nonviolence toward (dalam Encyclopedia of Violence, Peace, and Conflict, Volume I) (New York: Academy Press, 1999), h. 1.

${ }^{43}$ http://psg. uii.ac.id/index.php/Opini/KDRT.html, (5 -12-2017).
} 
b) Masalah ekonomi, dimana kecenderungan jika sebuah keluarga sedang terhimpit masalah keuangan akan mungkin menimbulkan tindakan-tindakan yang dapat berbentuk kekerasan dan juga tidak menutup kemungkinan bagi keluarga yang dipandang cukup dari segi ekonomi bisa jadi kegoisan akan muncul.

c) Masalah psikologi dari pasangan, jika salah satu dari suami istri memiliki tempramen yang tinggi (emosional) dan bahkan dengan mudah "main tangan", hal ini juga bisa menjadi pemicu.

d) Masalah seksual, banyak orang beranggapan istri adalah pihak yang subordinat terutama dalam hal urusan ranjang karena dianggap hanya sebagai pemuas, namun hal tersebut salah besar karena ada kesetaraan dalam hal ini. Tapi pada kenyataan ada pasangan yang tidak "puas" sehingga akan memunculkan kekerasan.

Paparan data tersebut bahwa faktor perselisihan dan pertengkaran, kekerasan dalam rumah tangga (KDRT), suami mabuk merupakan faktor yang simultan terintegritas dalam konflik perkawinan. Temuan kekerasan dalam rumah tangga tidak hanya berlaku dari suami terhadap isteri akan tetapi ditemukan juga bahwa KDRT juga dialami oleh suami meskipun dengan intensitas permasalahan kasus yang terjadi sedikit, baik kekerasan dalam bentuk fisik maupun psikis. Hal tersebut membuat pasangannya tidak dihargai, diremehkan, dan tidak diperlakukan selayaknya senagai pemimpin rumah tangga.

Dari tabel 4.1 dan 4.2 di atas menujukkan bahwa faktor perselisihan dan pertengkaran menempati urutan ke pertama dengan jumlah 535 perkara. Faktor suami mabuk menempati urutan ke enam dengan jumlah 10 perkara. Sedangkan penganiayaan/ Kekerasan Dalam Rumah Tangga menempati urutan ke tujuh dengan jumlah 6 perkara.

2. Meninggalkan Pasangan, Selingkuh (wanita Idaman Lain/ Pria Idaman Lain) dan Poligami

Tanggung jawab merupakan salah satu kewajiban yang harus dilaksanakan pasangan dalam berkeluarga. Meskipun ada perbedaan yang mendasar dalam pelaksanaannya oleh suami isteri. Saling melengkapi dan bersama-sama melaksanaan tugas sesuai dengan perannya tidak akan menjadi beban yang berat di antara pasangan suami isteri.

Tanggungjawab suami isteri dalam Islam diatur berdasar pada prinsipprinsip yang terdapat dalam al-Quran dan sunah Rasul saw. yang akhirnya menjadi kewajiban-kewajiban, hak-hak, perintah-perintah, dan larangan-larangan bagi suami isteri. Prinsip-prinsip yang ada dalam al-Qur'an dan sunah yang memuat persoalan keadilan, solidaritas kemanusiaan dan sportifitas akhirnya menimbulkan batas-batas kewajiban dan hak asasi manusia baik secara individual maupun secara kolektif. Atas dasar prinsip-prinsip tersebut dapat pula melahirkan suatu situasi yang penuh dengan toleransi, memelihara jarak dan timbal balik sebagai implementasi prinsip 
amar ma'ruf nahi mungkar yang tidak mengabaikan prinsip otoritas pribadi sesesorang atau hak asasi manusia. ${ }^{44}$

Dengan demikian peran dan fungsi suami isteri dalam keluarga adalah mutlak diperlukan, sebab hal ini sangat terkait dengan permasalahan hak dan kewajiban setiap anggota dalam keluarga. Keharmonisan dan kemashalatan keluarga akan tercipta dari adanya keseimbangan antara dijalankannya kewajiban dan diperolehnya hak. ${ }^{45}$

Beberapa peristiwa yang ditemukan di Kabupaten Sambas terdapat pasangan suami isteri yang meninggalkan pasangan dengan berbagai alasan, diantarnya, isteri tidak melayani kebutuhan lahir dan bathin suaminya, keegoisan suami tidak bisa menerima kekurangan isterinya dalam pelayanan kebutuhan keseharian, begitu juga isteri yang meninggalkan suaminya, karena suami tidak bisa mencukupi kebutuhan rumah tangganya secara materi, bahkan kebutuhan biologisnya.

Faktor cemburu juga merupakan suatu keadaan sikap yang dialami pasangan suami istri dan berpengaruh terhadap keadaan rumah tangga. Cemburu adalah perasaan tidak senang terhadap hal yang dilakukan oleh seseorang yang dicintai karena dinilai mengabaikan kepentingan dirinya. Cemburu bisa saja jadi faktor pencetus permusuhan antara suami isteri, karena itu suami atau isteri harus dapat menjauhkan diri dari hal-hal yang meninggalkan kecemburuan, baik berupa ucapan, perbuatan, dan sebagainya.

Minimnya pemahaman ilmu agama Islam pasangan suami isteri, sehingga pendekatan yang dipakai dalam menghadapi persoalan dalam rumah tangga lebih mengedepankan nilai-nilai emosional dan lebih mengedepankan pemenuhan kepuasan sepihak dari pribadi masing-masing.

Perselingkuhan banyak dialami dalam kehidupan rumah tangga pada saat ini. Faktor perdorong terjadinya perselingkuhan selain motif balas dendam adanya kesempatan, kurang perhatian dan seterusnya membuat kehidupan isteri menjadi tidak berarti. ${ }^{46}$

Meninggalkan pasangan, poligami dan Perselingkuhan, mengakibatkan ketidakharmonisan serta pembuka sengketa pemicu konflik perkawinan. Melihat data tabel 4.1 dan table 4.2 di atas menunjukkan bahwa meninggalkan pasangan dan perselingkuhan menempati urutan ke dua terbesar yang berjumlah 411 perkara, faktor poligami menempati urutan ke lima sebanyak 14 perkara.

3. Faktor Ekonomi

Ekonomi merupakan hal yang dianggap penting dalam kelancaran kehidupan berumah tangga. Segala kebutuhan rumah tangga dapat terpenuhi jika

\footnotetext{
${ }^{44}$ Marcel A. Boisard, Humanisme Dalam Islam (Jakarta: Bulan Bintang, 1980), h.107.

${ }^{45}$ Sidi Nazar Bakri, Kunci Keutuhan Keluarga, (Cet. I; Jakarta: Pedoman Ilmu Jaya, 1993), h. 37.

${ }^{46}$ Kholid O.S. Selingkuh Trend Baru Perilaku Mayarakat Kontemporer, h. 53.
} 
ekonominya lancar, tapi sebaliknya kericuhan-kericuhan rumah tangga sering terjadi yang kadang-kadang diakhiri oleh perceraian, ini disebabkan oleh masalah ekonomi yang tidak stabil. ${ }^{47}$

Tidak sedikit kasus kegagalan menciptakan keluarga sakinah dan bahkan menjadi retak berantakan disebabkan keadaan ekonomi keluarga yang kurang stabil. Bahkan persoalan ekonomi keluarga ini seringkali mempengaruhi perkembangan kadar keimanan seseorang. Karena itu keluarga perlu memperhatikan kestabilan ekonomi untuk mencapai predikat keluarga sakinah. ${ }^{48}$

Semua terkait disebabkan oleh faktor ekonomi yang minim tidak dapat memenuhi kebutuhan dalam sebuah rumah tangga dalam ikatan perkawinan. Dengan melihat tabel 4.1 dan 4.2 di atas menunjukkan bahwa faktor ekonomi menempati urutan ke dua di antara faktor-faktor konflik y yang terjadi dalam perkawinan yang diterima BP4 Kabupaten Sambas yaitu sebanyak 146 perkara.

4. Faktor dihukum penjara, murtad dan kawin paksa.

Pasangan yang mengalami sangsi hukuman mengakibatkan tanggung jawab keluarga tidak terpenuhi, terutama pihak suami yang mengalami hal demikian. Sebagai tulangpunggung keluarga, suami tidak dapat memenuhi kewajiban ke atas keluarganya akibat sangsi hukum yang harus dijalani. Berakibat ketidaksiapan anggota keluarga yang ditinggalkan, terutama bagi istri. Seiring waktu pertahanan keutuhan rumah tangga tidak mampu ditanggung seorang diri oleh istri dengan segala keterbatasan. Persoalan mulai bermunculan seiring perkembangan waktu yang cukup lama.

Kondisi lain ditemukan dari data lapanngan bahwa satu diantara penyebab faktor konflik perkawinan yaitu, murtad. Murtad merupakan keluarnya seseorang dari keyakinan agama yang dianutnya. Murtadnya salah satu pasangan disebabkan keluarnya pasangan dari keyakinan agama semula, terutama agama Islam. Terutama pasangan suami yang ketika berkeinginan menikah dengan calon istri ataupun suami yang beragama Islam, mengikuti sesuai ketentuan Undang-undang yang berlaku tanpa adanya unsur paksaan. Murtad merupakan salah satu faktor menyebabkan perceraian dalam perkawinan.

Dari hasil temuan faktor-faktor penyebab konflik perkawinan di Kabupaten Sambas terklasifikasi dalam beberapa hal diantaranya, yaitu; Faktor pertengkaran berjumlah 535 perkara, faktor suami mabuk berjumlah 11 perkara dan Kekerasan Dalam Rumah Tangga (KDRT) berjumlah 6 perkara; faktor ekonomi berjumlah 146 perkara perkara; faktor meninggalkan pasangan berjumlah 411 perkara, poligami berjumlah 14 perkara dan zina sebanyak 4 perkara; faktor dihukum penjara

${ }^{47}$ Departemen Agama R.I. Ditjen BIMAS dan Penyelenggara Haji, Modul Fasilitator Kursus Calon Pengantin (Jakarta: DEPAG R.I, 2001), h. 124-126.

${ }^{48}$ Departemen Agama R.I, Ditjen Bimas Islam dan Penyelenggaraan Haji, Modul Fasilitaor Kursus Calon Penganti, h. 124-126. 
berjumlah 3 perkara, murtad berjumlah 3 perkara, dan kawin paksa sebanyak 2 perkara.

\section{Resolusi Konflik Perkawinan}

Pengelolaan konflik merupakan cara yang digunakan individu dalam mengontrol, mengarahkan, dan menyelesaikan konflik, ${ }^{49}$ dalam hal ini adalah konflik interpersonal. Berdasarkan beberapa pendapat tentang pengelolaan konflik yaitu menurut Hodge dan Anthony, memberikan gambaran melalui berbagai metode resolusi (penyelesaian) konflik, yakni paksaan, penghalusan (smoothing) dan demokratis. ${ }^{50}$

Pertama, dengan metode penggunaan paksaan. Orang sering menggunakan kekuasaan dan kewenangan agar konflik dapat diredam atau dipadamkan. Kedua, dengan metode penghalusan (smoothing). Pihak-pihak yang berkonflik hendaknya saling memahami konflik dengan bahasa kasih sayang, untuk memecahkan dan memulihkan hubungan yang mengarah pada perdamaian. Ketiga, penyelesaian dengan cara demokratis. Artinya, memberikan peluang kepada masing-masing pihak untuk mengemukakan pendapat dan memberikan keyakinan akan kebenaran pendapatnya sehingga dapat diterima oleh kedua belah pihak. ${ }^{51}$

Sedangkan menurut Winardi, penyelesaian konflik dilakukan dengan tiga cara yaitu dengan dominasi atau supremasi, kompromi dan integrasi.

1. Metode dominasi atau supremasi

Metode ini sama-sama berusaha menekan konflik, bukannya menyelesaikan. Dominasi atau supremasi ini menjelma dalam berbagai macam bentuk, diantaranya; Pertama, memaksa (forcing), paksaan biasanya dilakukan oleh mereka yang berkuasa, sedangkan bawahan harus menerima tanpa argumen. Cara ini dapat menimbulkan konflik secara tidak langsung, namun destruktif. Kedua, membujuk (smoothing), Ketiga, membujuk merupakan cara yang lebih diplomatis karena dicapai dengan cara mengurangi ketidaksetujuan yang ada. Keempat, menghindari (avoidance). Pemimpin yang tidak memberikan solusi tepat, atau menolak memberikan keputusan karena tidak mau turut campur, maka dapat menimbulkan rasa ketidakpuasan. Kalima, Keinginan mayoritas (majority rule), keinginan mayoritas berarti mencapai pendapat yang terbanyak (pemungutan suara). Mungkin cara ini lebih fair, tetapi jika satu pihak itu saja yang terus menerus menang, maka pihak yang kalah dapat merasa frustasi.

\footnotetext{
${ }^{49}$ http://kanalom.blogspot.com/2010/03/pola-penyelesaian-konflik.html, diakses tanggal 23 Oktober 2017.

${ }^{50}$ http://kanalom.blogspot.com/2010/03/pola-penyelesaian-konflik.html, diakses tanggal 23 Oktober 2017.

${ }^{51}$ http://kanalom.blogspot.com/2010/03/pola-penyelesaian-konflik.html, diakses tanggal 20 Oktober 2017.
} 


\section{Kompromi}

Kompromi dicapai dengan jalan mengorbankan sasaran-sasaran tertentu untuk mencapai sasaran lain yang lebih baik. Bentuk-bentuk kompromi tersebut mencakup:

a) Separasi (separtion). Pihak yang berkonflik berpisah sampai mereka mencapai pemecahan.

b) Arbitrasi (arbitration). Dengan arbitrasi, mereka yang berkonflik tunduk terhadap keputusan pihak ketiga (biasanya atasan).

c) Faktor kebetulan (settling by change), seperti mentaati perat uran yang ada.

d) Menyogok (bribing), yaitu salah satu pihak menerima imbalan tertentu untuk mengakhiri konflik yang terjadi.

Pengendalian dengan cara mediasi, dengan maksud bahwa pihak-pihak yang berkonflik bersepakat untuk menunjuk pihak ketiga yang akan memberikan nasihatnasihat, berkaitan dengan penyelesaian terbaik terhadap konflik yang mereka alami. Mediasi penting ketika sejumlah pihak yang bertikai harus meminta kenyataan bahwa melanjutkan konflik nampaknya tidak akan membuat mereka mencapai tujuan. ${ }^{52}$ Adapun elemen yang terdapat dalam mediasi, menurut Curle, sebagaimana dikutip oleh Miall ada empat:

1) Tindakan mediator untuk membangun, mempertahankan dan meningkatkan komunikasi.

2) Menyediakan informasi untuk dan antara pihak-pihak yang bertikai.

3) "Menjadi teman" pihak-pihak yang bertikai.

4) Mendorong mediasi aktif. Memperkuat keinginan untuk terlibat dalam negosiasi kerjasama. $^{53}$

3. Integrasi

Integrasi ialah menyelesaikan konflik dengan menggunakan teknik-teknik pemecahan masalah.

1) Konsensus

Ada tiga tipe macam cara ini, yaitu:

Pihak-pihak yang berkonflik bertemu untuk menemukan pemecahan terbaik bagi problem yang ada, dan tidak saling menang sendiri.

2) Konfrontasi

Masing-masing pihak mengutarakan pandangan secara langsung terhadap yang lain.

3) Penggunaan tujuan-tujuan superordinat

\footnotetext{
${ }^{52}$ Hugh Miall, dkk., Resolusi Konflik Damai Kontemporer: Menyelesaikan, Mencegah, Mengelola dan Mengubah Konflik Bersumber Politik, Sosial, Agama dan Ras, terj. Tri Budhi Satrio (Jakarta: RajaGrafindo Persada, 2002), h. 255.

${ }^{53}$ Hugh Miall, dkk., Resolusi Konflik Damai Kontemporer: Menyelesaikan, Mencegah, Mengelola dan Mengubah Konflik Bersumber Politik, Sosial, Agama dan Ras, terj. Tri Budhi Satrio, h. 258 .
} 
Tujuan superordinat merupakan tujuan yang lebih tinggi dibandingkan dengan tujuan masing-masing kelompok, yang disetujui oleh semua pihak.

Tiga macam penyelesaian konflik di atas dapat dipilih salah satunya, atau dapat juga dikulaborasikan dalam penggunaannya. Penentuan metode solusi tergantung bagaimana situasi dan kondisi konflik yang dihadapi.

\section{PENUTUP}

Berdasarkan analisis penelitian, konflik perkawinan di Kabupaten Sambas yang telah teridentifikasi sebelumnya dengan menggunakan pendekatan metode fenomenalogi, dakwah, sosiologi dan komunikasi dalam konflik dan metode yang dilakukan dalam meresolusi konflik perkawinan tersebut adalah:

Jenis konflik perkawinan dalam rumah tangga di Kabupaten Sambas yaitu: faktor pertengkaran, Kekerasan Dalam Rumah Tangga (KDRT) dan faktor suami mabuk. Faktor pertengkaran dilatarbelakangi oleh tidak adanya kesepahaman suami dan isteri, suami pemakai oba-obat terlarang dan suka main judi. Kekerasan dalam rumah tangga berakibat penderitaan fisik maupn psikis. Bentuk kata-kata kasar dan jorok dari suami membuat isteri tersinggung, dilecehkan, tertekan akibat perkataan dan sikap suami; Faktor ekonomi Ekonomi disebabkan tingkat pendapatan suami dibandingkan isteri, isteri tidak dapat mengatur pendapatan suami dengan bijak, ketidakjujuran isteri terhadap suami. Meninggalkan Pasangan, Selingkuh (wanita Idaman Lain/ Pria Idaman Lain) dan Poligami; Faktor dihukum penjara, murtad dan kawin paksa.

\section{DAFTAR PUSTAKA}

Abdullah, Amin. Agama dan Resolusi Konflik Makalah Seminar Nasional. Yogyakarta: 14 Maret 2008.

Anggraini, Cyntia. Peran BP4 dalam Mengatasi Problem Perkawinan pada Pasangan Suami Isteri di Kec. Kartasura Kab Sukoharjo: STAIN, 2007.

A. Basyir. Hukum Perkawinan Islam. Yogyakarta: Bagian Penerbitan Fakultas Hukum Universitas Islam Indonesia, 1987.

Adhim, Mohammad Fauzil. Disebabkan oleh Cinta, Kupercayakan Rumahku Padamu. Yogyakarta: Mitra ustaka, 1999.

Akbar, H. Ali. Dasar-Dasar Konseptual Penanganan Masalah Bimbingan dan Konseling Islami dalam Bidang Pernikahan: dalam Rumusan Seminar Nasional Bimbingan dan Konseling Islami II. Yogyakarta: UUI Badan Pembinaan dan Pemgembangan Keagamaan, 1987.

Boisard, Marcel A. Humanisme Dalam Islam. Jakarta: Bulan Bintang, 1980.

Berry, David. Pokok-pokok Pikiran dalam Sosiologi. Jakarta: PT. Raja Grafindo Persada, 2004. 
Bugin, Burhan. Analisis Data Penelitian Kualitatif: Pemahaman Filosofis dan Metodologis ke Arah Penguasaan Model Aplikasi. Cet: I; Jakarta: Grafindo Persada, 2005.

Calleja, James. Aged Population, violence and Nonviolence toward (dalam Encyclopedia of Violence, Peace, and Conflict, Volume I). New York: Academy Press, 1999.

Data Cerai Talak dan Cerai Gugat di Pengadilan Agama Kabupaten Sambas Tahun 2018.

Departemen Agama. Modul Materi Pelatihan Korps Penasihat Perkawinan dan Keluarga Sakinah. Jakarta: Ditjen Bimas Islam dan Penyelenggaraan Haji Proyek Peningkatan Kehidupan Keluarga Sakinah, 2004.

Depdikbud. Kamus Besar Bahasa Indonesia, Jakarta: Balai Pustaka, 1994.

Departemen Agama R.I. Ditjen BIMAS dan Penyelenggara Haji, Modul Fasilitator Kursus Calon Pengantin. Jakarta: DEPAG R.I, 2001.

EB Surbakti. Sudah Siapkan Menikah. Jakarta: Kompas Gramedia, 2008.

Firdaweri. Hukum Islam Tentang Fasakh Perkawinan. CV. Pedoman Ilmu Jaya, 1989.

G. Pruitt, Dean dan Jeffrey Z. Rubin. Social Conflict Escalation, Stalemate, and Settlement, terj. Helly P. Soetjiptodan Sri Mulyantini Soetjipto. Teori Konflik Sosial. Yogyakarta: Pustaka Pelajar, 2004.

Hadari, Dadang. Al-qur'an Ilmu Kedokteran dan Kesehatan Jiwa. Yogyakarta: Dana Bakti rima Yasa, 1997.

Hendricks, William. Bagaimana Mengelola Konflik: Petunjuk Praktis untuk Manajemen Konflik yang Efektif, terj. Ariff Santoso. Jakarta: Bumi Aksara, 1996.

Hurlock. Psikologi Perkembangan Suatu Pendekatan Sepanjang Rentang Kehidupan. Jakarta: Erlangga.

Kadri, Has. Adat Istiadat Perkawinan Melayu Sambas. Pontianak: Romeo Grafika, 2000.

Kholid O.S. Selingkuh Trend Baru Perilaku Mayarakat Kontemporer. Bandung: Sega Arsy, 2004.

Lihat Pemda Sambas, Bagian Humas.

Lederach, John Paul. The Little Books Conflict Transformatio. USA: Good Books, 2003.

Margaret, Poloma Sosiologi Kontemporer. Jakarta: Raja Grafindo Persada, 2010.

Miall, Hugh dkk. Resolusi Konflik Damai Kontemporer: Menyelesaikan, Mencegah, Mengelola dan Mengubah Konflik Bersumber Politik, Sosial, Agama dan Ras, terj. Tri Budhi Satrio. Jakarta: RajaGrafindo Persada, 2002.

Moloeng, Lexi J. Metodologi Penelitian Kualitatif. Bandung: Remaja Rosdakarya, 1990.

Nazar Bakri, Sidi. Kunci Keutuhan Keluarga, cet. Ke-I. Jakarta: Pedoman Ilmu Jaya, 1993. 
Nugroho, T. Sumarno. Sistem Intervensi Kesehatan Sosial. Yogyakarta: PT. Hanindita, 1991.

Prawirohamidjojo, Soetojo dkk. Hukum Orang dan Keluarga, Bandung: Alumni, Cetakan Kesebelas, 2000.

Sanafiah, Faisal. Penelitian Kualitatif: Dasar-Dasar dan Aplikasi. Jakarta: Rajawali Press, 1995.

Saleh, K. Wantjik. Hukum Perkawinan Indonesia. Jakarta Timur: Ghalia Indonesia 1982.

Soekanto, Soerjono. Sosiologi Keluarga: Tentang Ikhwal Keluarga Remaja dan Anak, Jakarta: Rineka Cipta, 2004, cet ke-3.

Usman, Rachmadi. Pilihan Penyelesaian Sengketa di Luar Pengadilan. PT. Citra Aditya Sakti: 2003.

Walgito, Bimo. Bimbingan dan Konseling Perkawinan. Yogyakarta: Penerbit Andi.

Faktor-Faktor Penyebab Konflik, https://www.siswapedia.com, diakses 05 Januari 2019.

Pontianak.tribunnews.com/2014/03

Sumber Internet:

http://kanalom.blogspot.com/2010/03/pola-penyelesaian-konflik.html, diakses tanggal 23 Oktober 2017.

http://psg. uii.ac.id/index.php/Opini/KDRT.html, (5 -12-2017).

htt://WWW.averroes.or.id/research/hubungan-sikap-terhadap-penundaan-usiaperkawinan-dengan-intensi-penundaan-perkawinan.html, diakses tanggal, 15 Desember 2017.

http:///library.usu.ac.id/download/fkm/fkm-juanita3.pdf, diakses tanggal 22 Oktober 2017. 